\title{
INTENSITAS DAN MOTIVASI MASYARAKAT DALAM PENGAMBILAN TUMBUHAN HUTAN SECARA ILEGAL DI SEKSI KONSERVASI WILAYAH II TAMAN NASIONAL GUNUNG GEDE PANGRANGO (Intensity and Motivation of Forest Plant Illegal Taking in Conservation Section II, Gede Pangrango National Park)*)
}

\author{
Oleh/By: \\ Aris Sudomo dan/and M. Siarudin \\ Balai Penelitian Kehutanan Ciamis \\ Jl. Raya Ciamis-Banjar Km. 4 PO. BOX. 5 Ciamis 46201 Telp. (0265) 771352, Fax (0265) 775866
}

*) Diterima : 13 Maret 2007; Disetujui : 05 Nopember 2008

\begin{abstract}
The research of intensity and motivation of forest plant illegal taking was conducted in 4 resorts of Conservation Section II of Gede Pangrango National Park (GPNP) : Resort of Bodogol, Resort of Cimande, Resort of Cisarua, and Resort of Bojong Murni. Data was collected by interviewing 118 respondents representing buffer zone communities of those 4 resorts. Data were analyzed using descriptive analysis. The result showed that the intensity of forest plant illegal taking out during the year 2005 was 9 cases in Resort of Cisarua, 11 cases in Resort of Bojong Murni, 3 cases in Resort of Cimande, and 14 case in Resort of Bodogol, with the plants stolen are: wood working (Altingia excelsa Noronha, Schima wallichii (DC) Korth.), wood for energy (Calliandra sp., bamboo Gigantochloa spp.), pakis (Diplazium sp.), and ornamental plant. The stealing agents come from the communities surrounding the forest area. Fuel wood illegal taking was the dominant case, occurred in all resorts and increased during 2003-2005; noted 16 loads was stolen in 2003; 32 loads in 2004; and 93 loads in 2005. Based on the information from the respondent about the sum of the citizens taking forest plants, the insecure rate are Resort of Cisarua, Resort of Cimande, Resort of Bodogol, and Resort of Bojong Murni respectively. The knowledge and understanding rate of communities about the national park existency still low, showed from 59.86\% communities who clarify not understand about the national park. Most of the community took the forest plants (bamboo and fuel wood) for their daily need $(88,2 \%)$, only view caused by the order of others person $(2,3 \%)$, or because they feel as usual activities and assumed as allowable activities (2,8\%). Their low education and income rate motivated them to interact the forest. Most of the communities who took forest plants are labours (66.2\%), with elementary school last education background (92.2\%), and under 100,000.00 rupiahs/month income (59.9\%).
\end{abstract}

Keywords: National park, forest plant, resort, fuel wood, illegal taking out

\begin{abstract}
ABSTRAK
Penelitian intensitas dan motivasi masyarakat dalam pengambilan tumbuhan hutan secara ilegal dilakukan di SKW II Taman Nasional Gunung Gede Pangrango yang meliputi empat resort yaitu : Resort Bodogol, Resort Cimande, Resort Cisarua, dan Resort Bojong Murni. Pengumpulan data dilakukan dengan wawancara atas dasar kuesioner terhadap 118 responden yang mewakili masyarakat sekitar hutan di empat resort tersebut. Data yang diperoleh dianalisis secara deskriptif. Hasil penelitian menunjukkan bahwa intensitas kasus pengambilan tumbuhan hutan secara ilegal tahun 2005 untuk setiap resort di SKW II TNGP adalah Resort Cisarua sembilan kasus, Resort Bojong Murni 11 kasus, Resort Cimande tiga kasus, dan Resort Bodogol 14 kasus dengan jenis-jenis tumbuhan yang diambil antara lain: kayu pertukangan (Altingia excelsa Noronha, Schima wallichii (DC) Korth.), kayu bakar (Calliandra sp., bambu Gigantochloa spp.), pakis (Diplazium sp.), dan tanaman hias. Pelaku pengambilan tumbuhan hutan secara ilegal berasal dari masyarakat sekitar hutan. Pengambilan kayu bakar secara ilegal merupakan gangguan yang dominan karena terjadi di semua resort dan semakin meningkat dalam kurun waktu 2003-2005; pada tahun 2003 tercatat 16 pikul, kemudian pada tahun 2004 tercatat 32 pikul, dan pada tahun 2005 mencapai 93 pikul. Berdasarkan jumlah penduduk yang mengambil tumbuhan hutan secara ilegal, urutan tingkat kerawanan terhadap gangguan hutan dari yang paling rawan adalah Resort Cisarua, Resort Cimande, Resort Bodogol, dan Resort Bojong Murni. Tingkat pengetahuan dan pemahaman masyarakat tentang keberadaan TNGP sebagai kawasan konservasi relatif masih rendah. Hal ini dapat dilihat dari 59,86\% masyarakat yang belum tahu keberadaan taman nasional. Pengetahuan dan pemahaman masyarakat dari masing-masing resort tentang TNGP dari yang tertinggi adalah Resort Bodogol, Resort Cisarua, Resort Cimande, dan Resort Bojong Murni. Sebagian besar masyarakat
\end{abstract}


sekitar hutan melakukan pengambilan tumbuhan hutan secara ilegal (bambu dan kayu bakar) untuk memenuhi kebutuhan sehari-hari (88,2\%), dan sebagian kecil karena perintah orang lain yang akan membeli hasilnya (2,3\%), atau karena sudah menjadi kebiasaan dan menganggap sebagai tindakan yang diperbolehkan (2,8\%). Penduduk yang melakukan pengambilan tumbuhan hutan secara ilegal (bambu dan kayu bakar) sebagian besar adalah buruh (66,2\%) yang rata-rata berpendidikan Sekolah Dasar (92,2\%) dan berpenghasilan di bawah Rp 100.000,00 per bulan (59,9\%).

Kata kunci: Taman nasional, tumbuhan hutan, resort, kayu bakar, pengambilan secara ilegal

\section{PENDAHULUAN}

Manfaat hutan berupa kayu hanya 5\% dari nilai total ekonomi sumberdaya hutan. Menggarap sisa 95\% dari manfaat hutan dapat dilakukan dengan pengelolaan hutan lindung dan kawasan konservasi. Sedikitnya ada 13 pelayanan jasa produk dari ekosistem pegunungan sebagai kawasan konservasi yang meliputi menjaga udara bersih, perlindungan banjir dan kemarau panjang, menjaga dari degradasi lingkungan, peningkatan kesuburan tanah, penyerbukan beberapa spesies asli lokal dan pengenalan spesies, pengendalian penyakit tumbuhan, penyebaran benih dan distribusi nutrisi, pengawetan keanekaragaman hayati, perlindungan dari sinar ultraviolet dan radiasi matahari, pemapanan iklim, pengendalian temperatur dan angin yang berlebihan, mendukung kebudayaan masyarakat, menjaga keindahan alam, dan mendukung kehidupan masyarakat (Kementerian Lingkungan Hidup, 2003). Taman Nasional Gunung Gede Pangrango (TNGP) merupakan salah satu dari lima taman nasional tertua di Indonesia, yang ditetapkan berdasarkan Pengumuman Menteri Pertanian tanggal 5 Maret 1980. Sebagai taman nasional, TNGP menjadi kawasan konservasi yang mempunyai fungsi paling lengkap, yaitu untuk perlindungan sistem penyangga kehidupan, pengawetan keanekaragaman hayati serta pemanfaatan secara lestari sumberdaya alam hayati dan ekosistemnya. Oleh karena itu kawasan ini perlu dikelola dengan baik.

Secara administratif kawasan TNGP mencakup tiga kabupaten yaitu Bogor, Cianjur, dan Sukabumi. Bagi masyarakat sekitar, kawasan taman nasional tersebut memiliki arti penting dari segi hidrologis, klimatologis, dan ekonomis dari sektor ekowisata. Namun keberadaan kawasan TNGP di tengah pemukiman padat tersebut seringkali mengalami permasalahan akibat interaksi masyarakat yang dapat mengancam kelestariannya. Beberapa permasalahan tersebut antara lain perambahan kawasan, pengambilan secara ilegal seperti pakis, kayu pertukangan, kayu bakar, dan rotan. Selain itu, pengambilan tanaman hias, perburuan liar, pengambilan bunga edelwies secara ilegal oleh pengunjung, sampah, dan vandalisme (TNGP, 2005).

Berbagai upaya telah dilakukan oleh pihak pengelola taman nasional untuk mengatasi gangguan kawasan antara lain dengan pelaksanaan patroli, pendidikan lingkungan, sosialisasi, dan pemberian bantuan usaha ekonomi pedesaan bagi masyarakat daerah penyangga. Namun demikian upaya untuk mengatasi gangguan tersebut masih perlu didukung dengan kajian terhadap kondisi wilayah dan gangguan kawasan hutan yang terjadi. Penelitian ini bertujuan untuk memperoleh informasi tentang besarnya intensitas dan penyebaran kasus pengambilan tumbuhan hutan secara ilegal di setiap resort di Seksi Konservasi Wilayah (SKW) II TNGP, serta informasi tentang motivasi dan latar belakang sosial ekonomi masyarakat yang menyebabkan masyarakat melakukan aktivitas pengambilan tumbuhan hutan secara ilegal. Informasi penelitian ini diharapkan dapat membantu pengelola taman nasional dalam mengambil kebijakan, khususnya dalam mengatasi gangguan kawasan hutan. 


\section{KEADAAN UMUM LOKASI}

\section{A. Keadaan Umum di Lokasi Kegiatan}

Seksi Konservasi Wilayah II Bogor termasuk dalam wilayah Kabupaten Bogor dan Sukabumi, serta terdiri dari empat resort yaitu Resort Bodogol, Resort Cimande, Resort Bojong Murni, dan Resort Cisarua.

\section{Resort Bodogol}

Resort Bodogol termasuk dalam kawasan SKW II Bogor-TNGP yang secara administratif kawasannya terletak di dua kabupaten, yaitu Kabupaten Bogor dan Kabupaten Sukabumi. Secara geografis terletak pada $06^{0} 32^{\prime}-06^{0} 34^{\prime}$ LS dan $106^{0}$ 50 '-106 $56^{\circ}$ ' BT. Luas wilayah hutan Resort Bodogol \pm 2.000 ha dan sejak tahun 2003 kawasannya diperluas menjadi 2.394,7 ha. Topografi Resort Bodogol bergunung-gunung dengan ketinggian tempat bervariasi antara 600-1.300 m dpl, kelas lereng $6,75^{\circ}-11,25^{\circ}, 11,25^{\circ}-18^{\circ}$, > $18^{\circ}$. Berdasarkan Peta Tanah Kabupaten Sukabumi skala 1 : 250.000 diketahui jenis tanah Bodogol adalah latosol coklat. Curah hujan rata-rata per tahun 3.000$4.000 \mathrm{~mm}$ yang termasuk dalam tipe iklim B menurut Schmidt dan Ferguson (1951), wilayah Resort Bodogol merupakan sebagian dari hutan hujan tropis dataran tinggi yang masih utuh di Pulau Jawa (PPKAB, 1999).

\section{Resort Cimande}

Daerah kerja Resort Cimande terletak di bagian barat kawasan TNGP dan terletak di Kabupaten Bogor. Wilayah kerja resort ini meliputi desa-desa Cinagara, Tangkil, Pancawati, Lemah Duhur, dan Cimande Jaya yang termasuk dalam Kecamatan Caringin. Luas daerah Resort Cimande \pm 1500 ha dan mempunyai topografi berbukit dengan ketinggian 900$3.019 \mathrm{~m}$ dpl. Kawasan ini hampir semuanya berbatasan langsung dengan kawasan hutan produksi Perum Perhutani Unit III Jawa Barat (KPH Bogor) dan lahan pertanian masyarakat. Curah hujan rata-rata per tahun adalah $4.000 \mathrm{~mm}$ dengan tipe iklim B menurut Schmidt dan Ferguson (1951) dengan jenis tanah yang dominan adalah latosol (TNGP, 2005).

\section{Resort Bojong Murni}

Wilayah kerja Resort Bojong Murni meliputi desa-desa Jambuluwuk, Citapen, Cileungsi, Cibedug, dan Bojong Murni yang termasuk Kecamatan Ciawi, serta Desa Sukaresmi di Kecamatan Megamendung. Luas kawasan ini adalah 1.050 ha (TNGP, 2005).

\section{Resort Cisarua}

Resort Cisarua terletak di bagian utara kawasan TNGP. Wilayah kerja resort ini meliputi desa-desa Sukagalih Kecamatan Megamendung, Kuta, Citeko, Cibeureum, Tugu Selatan, dan Tugu Utara (Kecamatan Cisarua, Kabupaten Bogor). Luas kawasan ini sekitar 1.279 ha dengan topografi berupa perbukitan sampai dengan pegunungan dengan variasi ketinggian 800-3.019 m dpl. Kawasan ini hampir semuanya berbatasan langsung dengan kawasan hutan produksi Perum Perhutani Unit III Jawa Barat (KPH Bogor), kebun teh PTP VIII Gunung Mas, dan lahan perkebunan serta lahan pertanian masyarakat. Curah hujan rata-rata per tahun adalah $3.200 \mathrm{~mm}$ yang termasuk dalam tipe iklim $\mathrm{B}$ dengan jenis tanah berupa jenis latosol coklat-andosol yang subur (TNGP, 2005).

\section{B. Gambaran Kondisi Sosial Ekonomi Masyarakat di Sekitar Kawasan}

Sebagian besar masyarakat (75\%) di sekitar kawasan TNGP memiliki mata pencaharian di bidang pertanian (land based activities). Namun, sekitar $40 \%$ di antaranya adalah buruh tani yang tidak mempunyai lahan garapan dan tergantung pada lahan orang lain. Di samping itu, tingkat pemilikan lahan rata-rata per keluarga relatif kecil yaitu kurang dari 0,25 ha sehingga intensitas garapan sangat tinggi. Menurut data monografi desa-desa di sekitar SKW II TNGP tahun 2003 dapat diketahui bahwa mata pencaharian 
penduduk sekitar SKW II TNGP berurutan dari yang terbanyak adalah petani (44,68\%), peternak (20,44\%), buruh (12,85\%), pedagang (3,5\%), pegawai perkebunan $(3,33 \%)$, PNS $(2,83 \%)$, wiraswasta lain (2,11\%), petani ikan (1,09\%), TNI (0,69\%), dan pekerjaan lainnya (8,49\%). Tingkat pendidikan penduduk di sekitar kawasan SKW II TNGP dari yang terbanyak adalah Sekolah Dasar (57,73\%), Sekolah Menengah Pertama (18,65\%), tidak tamat Sekolah Dasar (13,07\%), Sekolah Menengah Atas (9,62\%), Diploma 1-Diploma $3(0,51 \%)$, Strata-1 (0,35\%), Strata-2 (0,05\%), dan Strata-3 (0,01\%).

\section{METODOLOGI}

\section{A. Lokasi dan Waktu Penelitian}

Penelitian dilakukan di SKW II TNGP yang meliputi empat resort yaitu Resort Bodogol, Resort Cimande, Resort Cisarua, Resort Bojong Murni, dari tanggal 6 Desember 2005 sampai dengan 18 Februari 2006.

\section{B. Pengumpulan Data}

\section{Data Primer}

Data primer diperoleh dengan wawancara dan kuesioner serta pengamatan langsung di lapangan. Wawancara dan kuesioner dilakukan terhadap 118 responden yang dipilih secara acak pada masyarakat sekitar hutan di empat resort di SKW II TNGP, yaitu Resort Bodogol, Resort Cisarua, Resort Cimande, dan Resort Bojong Murni. Pengumpulan data primer juga dilakukan dengan pengamatan secara langsung di lapangan tentang pola kehidupan masyarakat. Beberapa parameter data yang dikumpulkan antara lain motivasi dan kondisi sosial ekonomi masyarakat yang menyebabkan aktivitas pengambilan tumbuhan hutan secara ilegal dan informasi tingkat kerawanan serta jumlah masyarakat yang telah melakukan aktivitas pengambilan tumbuhan hutan secara ilegal.

\section{Data Sekunder}

Data pokok yang berupa intensitas pengambilan tumbuhan hutan secara ilegal dapat diperoleh dari hasil penangkapan oleh pihak keamanan kawasan yang terdapat dalam laporan bulanan sepanjang tahun 2005. Besarnya pengambilan tumbuhan hutan secara ilegal diperoleh dari Laporan Tahunan TNGP yang berasal dari hasil patroli rutin maupun operasai gabungan/operasi fungsional selama tiga tahun yaitu tahun 2003-2005.

\section{Analisis Data}

Data yang diperoleh dianalisis secara deskriptif. Data sekunder mengenai intensitas pengambilan tumbuhan hutan secara ilegal dikelompokkan berdasarkan bulan dan lokasi kejadian sepanjang tahun 2005 dan mengenai besarnya jenis-jenis tumbuhan hutan yang hilang dikelompokkan berdasarkan lokasi kejadian selama kurun waktu 2003-2005.

Data dan informasi mengenai jumlah masyarakat yang melakukan aktivitas pengambilan tumbuhan hutan secara ilegal dikelompokkan berdasarkan setiap resort. Analisis data motivasi dan kondisi sosial ekonomi masyarakat yang menyebakan aktivitas pengambilan tumbuhan hutan secara ilegal dilakukan secara deskriptif dengan pengelompokan berdasarkan setiap resort. Persepsi masyarakat tentang keberadaan TNGP dikelompokkan berdasarkan tingkat pengetahuan dan pemahaman di setiap resort.

\section{HASIL DAN PEMBAHASAN}

\section{A. Intensitas dan Penyebaran Peng- ambilan Tumbuhan Hutan Secara Ilegal Tahun 2005}

Intensitas dan penyebaran pengambilan tumbuhan hutan secara ilegal dibagi berdasarkan lokasi kejadian, jenis pengambilan, bulan kejadian, dan jumlah kasus dalam setahun. Intensitas dan penyebaran pengambilan tumbuhan hutan secara 
ilegal di SKW II TNGP selama satu tahun terakhir (tahun 2005) disajikan pada Tabel 1 .

Dari Tabel 1 dapat dilihat bahwa pengambilan jenis kayu bakar secara ilegal merupakan gangguan yang dominan di SKW II TNGP karena terjadi di semua resort dan terjadi hampir sepanjang tahun 2005. Intensitas pengambilan kayu bakar secara ilegal tertinggi terjadi di Resort Bojong Murni, diduga karena resort tersebut relatif baru dan sistem pengamanan belum berjalan dengan baik. Secara umum intensitas pengambilan tumbuhan hutan secara ilegal di Resort Cimande paling kecil dibanding resort lainnya. Berdasarkan hasil wawancara, masyarakat me- lakukan pengambilan tumbuhan hutan secara ilegal dengan alasan untuk memenuhi kebutuhan sehari-hari seperti yang disajikan pada Tabel 5. Masyarakat Resort Cimande melakukakan pengambilan tumbuhan hutan secara ilegal dengan alasan memenuhi kebutuhan sehari-hari dengan persentase terkecil dibanding resort lain, jadi relatif mempunyai alasan lain seperti perintah orang lain yang akan membelinya. Data perbedaan intensitas pengambilan tumbuhan hutan secara ilegal antar resort selain dipengaruhi oleh tingkat kerawanan yang berbeda dapat disebabkan oleh kapasitas tingkat pengamanan masing-masing resort yang berbeda.

Tabel (Table) 1. Intensitas dan penyebaran pengambilan tumbuhan hutan secara ilegal pada setiap bulannya di tahun 2005 (Intensity and distribution of forest plant illegal taking out by month during 2005)

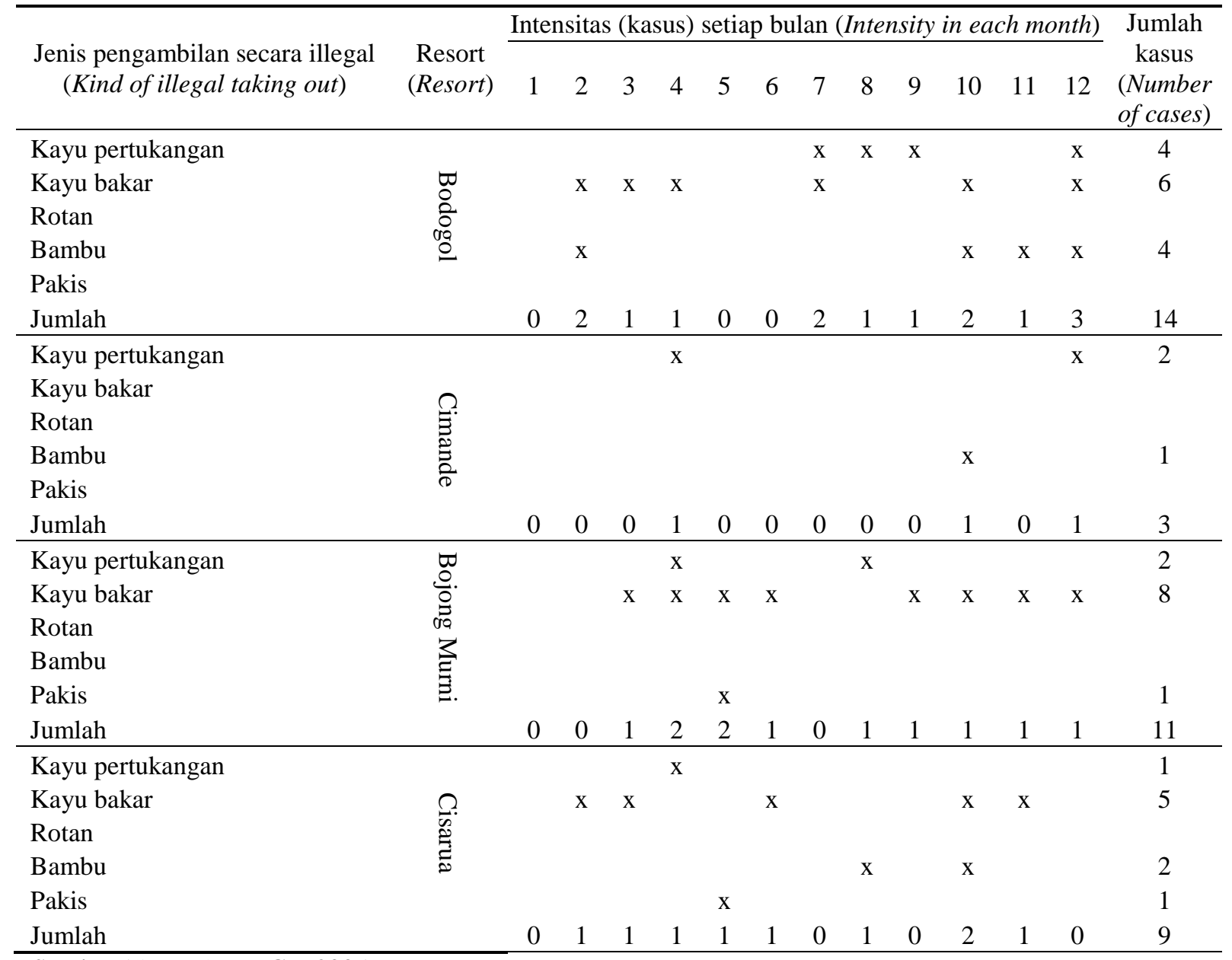

Sumber (Source) : TNGP, 2005 


\section{B. Besarnya Pengambilan Tumbuhan Hutan Secara Ilegal dalam Kurun Waktu 2003-2005}

Besar dan jenis pengambilan secara ilegal setiap resort di SKW II TNGP berbeda-beda. Besarnya pengambilan tumbuhan hutan secara ilegal di setiap resort pada kurun waktu 2003-2005 disajikan dalam Tabel 2.

Berdasarkan Tabel 2, jenis-jenis pengambilan tumbuhan hutan secara ilegal di SKW II TNGP ini dapat diuraikan sebagai berikut:

1) Pengambilan Kayu Pertukangan Secara Ilegal

Volume pengambilan kayu pertukangan secara ilegal terbesar sepanjang tahun 2003-2005 terjadi di Resort Bodogol, diduga hal ini disebabkan oleh keberadaan masyarakat Resort Bodogol relatif lebih dekat dengan hutan dibanding resort lainnya sehingga lebih sering intervensi ke dalam kawasan hutan. Meskipun demikian tingginya volume pengambilan kayu pertukangan secara ilegal tidak selalu terjadi di Resort Bodogol. Menurut Ekawati
(2000) volume kehilangan pohon antara satu sampai empat pohon di setiap resort dengan perkecualian pada tahun 1997/ 1998 terjadi kehilangan yang cukup besar di Resort Cisarua, yaitu mencapai 16 pohon. Jenis pohon yang ditebang adalah damar, rasamala, dan huru serta jenis kayu rimba lain.

2) Pengambilan Kayu Bakar Secara Ilegal

Pada Tabel 2 secara umum dapat dilihat bahwa pengambilan kayu bakar secara ilegal di SKW II mengalami peningkatan selama kurun waktu 2003 hingga 2005. Kecenderungan peningkatan pengambilan kayu bakar secara ilegal ini diperkirakan karena tingkat pemenuhan kebutuhan hidup yang semakin tinggi dengan bertambahnya kepadatan penduduk dan menurunnya tingkat kesejahteraan serta kenaikan harga bahan bakar minyak yang menyebabkan masyarakat cenderung menggunakan kayu bakar. Menurut Ekawati (2000) pengambilan kayu bakar secara ilegal merupakan bentuk gangguan yang masih dominan di TNGP dan hampir terjadi di semua resort. Menurut

Tabel (Table ) 2. Pengambilan tumbuhan hutan secara ilegal tahun 2003-2005 (Forest plants illegaly taking out during the year 2003-2005)

\begin{tabular}{|c|c|c|c|c|c|c|c|c|}
\hline \multirow[t]{2}{*}{ No } & \multirow[t]{2}{*}{$\begin{array}{l}\text { Jenis pengambilan } \\
\text { secara illegal (Kind } \\
\text { of illegal taking out) }\end{array}$} & \multirow[t]{2}{*}{$\begin{array}{l}\text { Tahun } \\
\text { (Year) }\end{array}$} & \multirow[t]{2}{*}{$\begin{array}{l}\text { Satuan } \\
\text { (Unit) }\end{array}$} & \multicolumn{4}{|c|}{$\begin{array}{c}\text { Jumlah tumbuhan hutan yang diambil secara } \\
\text { ilegal di setiap sector (Number of forest plant } \\
\text { illegally taking out in every sector) }\end{array}$} & \multirow[t]{2}{*}{$\begin{array}{l}\text { Jumlah } \\
\text { (Total) }\end{array}$} \\
\hline & & & & Bodogol & Cimande & Bojong Murni & Cisarua & \\
\hline \multirow[t]{3}{*}{1} & \multirow{3}{*}{$\begin{array}{l}\text { Kayu pertukangan } \\
\text { (Timber) }\end{array}$} & 2003 & $\mathrm{~m}^{3}$ & 17 & 5,5 & 2,5 & 3,5 & 28,5 \\
\hline & & 2004 & $\mathrm{~m}^{3}$ & 2,146 & 1,16 & 1,098 & 1,037 & 5,41 \\
\hline & & 2005 & btg pohon & 11 & 7 & 2 & 2 & 22 \\
\hline \multirow[t]{3}{*}{2} & \multirow{3}{*}{$\begin{array}{l}\text { Kayu bakar } \\
\text { (Fuelwood) }\end{array}$} & 2003 & Pikul & 1 & - & 2 & 13 & 16 \\
\hline & & 2004 & Pikul & 2 & 4 & 19 & 7 & 32 \\
\hline & & 2005 & Pikul & 19 & & 63 & 11 & 93 \\
\hline \multirow[t]{3}{*}{3} & \multirow[t]{3}{*}{ Bambu (Bamboo) } & 2003 & Batang & 236 & 50 & - & - & 286 \\
\hline & & 2004 & Batang & 23 & 5 & 16 & 15 & 59 \\
\hline & & 2005 & Batang & 40 & 3 & - & 7 & 50 \\
\hline \multirow[t]{3}{*}{4} & \multirow{3}{*}{$\begin{array}{l}\text { Pakis } \\
\text { (Diplazium sp.) }\end{array}$} & 2003 & Batang & - & 10 & - & - & 10 \\
\hline & & 2004 & Batang & - & - & - & 31 & 31 \\
\hline & & 2005 & Karung & & & 3 & 1000 & 1003 \\
\hline \multirow[t]{3}{*}{5} & \multirow{3}{*}{$\begin{array}{l}\text { Tanaman hias } \\
\text { (Ornamental plant) }\end{array}$} & 2003 & Batang & - & - & - & - & - \\
\hline & & 2004 & Batang & 26 & - & - & - & 26 \\
\hline & & 2005 & Batang & - & - & - & - & - \\
\hline
\end{tabular}

Sumber (Source) : TNGP, 2003-2005 
hasil wawancara yang dilakukan, hal ini terjadi karena kondisi sosial ekonomi masyarakat sekitar TNGP yang relatif rendah dan umumnya masih menggunakan kayu bakar sebagai sumber energi untuk memasak atau memenuhi kebutuhan hidup sehari-hari. Namun demikian, ada sebagian masyarakat yang memanfaatkan kayu bakar selain untuk keperluan memasak juga memperjualbelikan guna memenuhi kebutuhan hidupnya seperti disajikan pada Tabel 5 .

Volume pengambilan kayu bakar secara ilegal di Resort Bojong Murni terbesar dibanding resort lain, sesuai dengan data pada Tabel 1 bahwa intensitas pengambilan kayu bakar secara ilegal di resort ini tertinggi. Hal ini disebabkan oleh keberadaan resort tersebut relatif baru sehingga sistem pengamanan belum berjalan dengan baik. Hal lain yang diduga mendorong tingginya pengambilan kayu bakar secara ilegal di resort ini adalah tingkat pendapatan penduduk yang paling rendah dibanding resort lain, sebagaimana disajikan pada Tabel 7. Meskipun demikian menurut Ekawati (2000) dari semua resort yang mengalami gangguan pengambilan kayu bakar secara ilegal, resort yang paling besar volumenya selama kurun waktu tahun 1995 sampai 1999 adalah Cisarua.

\section{3) Pengambilan Bambu Secara Ilegal}

Pada Tabel 2 secara umum volume pengambilan bambu secara ilegal menúrun selama kurun waktu 2003-2005. Fenomena ini berbeda dengan pengambilan kayu bakar secara ilegal yang digunakan sebagai bahan bakar memasak untuk memenuhi kebutuhan sehari-hari sehingga intensitas pengambilan secara ilegal meningkat seiring dengan peningkatan kepadatan penduduk. Sedangkan bambu tidak digunakan untuk kebutuhan sehari-hari sehingga tidak secara langsung berkaitan dengan peningkatan jumlah penduduk.

Volume pengambilan bambu secara ilegal di Resort Bodogol tertinggi dibanding resort lain, diduga karena keberadaan bambu yang umumnya hidup di pinggir hutan, yaitu zona sub montana memudahkan masyarakat untuk mengambilnya. Berdasarkan informasi masyarakat hal ini dilakukan karena petani membutuhkan ajir-ajir untuk tanaman pertanian dan peternak domba mengambil bambu secara ilegal biasanya untuk bahan baku pembuatan kandang ternak.

\section{4) Pengambilan Pakis Haji Secara Ilegal}

Pada Tabel 2 pengambilan pakis haji secara ilegal terbesar di Resort Cisarua pada tahun 2005 sebanyak 1.000 karung atau sekitar 15 ton. Hal ini kemungkinan disebabkan tingkat kelimpahan jenis pakis haji yang relatif lebih tinggi di Resort Cisarua dibanding resort lain. Menurut Ekawati (2000) pakis haji sebagai bahan dasar untuk menempelkan tanaman hias yang sering diperjualbelikan oleh para pengusaha bunga/tanaman hias, umumnya diambil dari kawasan hutan dan lahan perkebunan. Biasanya para pengusaha tanaman hias memberikan modal kepada para petani atau buruh untuk mengumpulkan pakis dari dalam hutan dan dikumpulkan pada suatu tempat dan kemudian diangkut setelah pakis terkumpul banyak. Satu batang pakis, umumnya berukuran panjang antara 2-3 meter dengan diameter sekitar $30 \mathrm{~cm}$, dijual dengan harga berkisar antara Rp 30.000,- - Rp 40.000,-.

\section{5) Pengambilan Tanaman Hias Secara Ilegal}

Pada Tabel 2 disebutkan bahwa pada tahun 2003 telah terjadi pengambilan tanaman hias secara ilegal di Resort Bodogol sebanyak 26 batang, tetapi hal ini tidak terjadi di resort-resort lain di wilayah SKW II. Hal ini disebabkan karena lokasi Resort Bodogol sebagai tempat rekreasi yang relatif lebih ramai dibanding resort lain dengan permintaan tanaman hias yang lebih tinggi. Hal ini mendorong masyarakat untuk memperjualbelikan tanaman hias kepada pengunjung. Pengambilan tanaman hias secara ilegal tidak terjadi di resort lain karena keberadaan tanaman hias di resort lain relatif tidak mudah 
dijangkau oleh masyarakat seperti di Resort Bodogol.

6) Pengambilan Rotan Secara Ilegal

Rotan sebagai bahan baku kerajinan dan anyaman banyak dijumpai di kawasan TNGP. Selama kurun waktu 2003 sampai 2005 tidak ditemukan kasus pengambilan rotan secara ilegal di SKW II TNGP. Meskipun demikian menurut Ekawati (2000) kasus pengambilan rotan secara ilegal pernah terjadi pada tahun-tahun sebelumnya, misalnya pada kurun waktu 1995 sampai 1999 dilaporkan kehilangan rotan berkisar pada jumlah 1-5 batang. Namun demikian pencurian rotan ini cenderung menurun dari tahun ke tahun bahkan tidak terjadi pada tahun keempat.

\section{7) Pengambilan Buah Konyal Secara} Ilegal

Pada Tabel 2 dapat dilihat selama kurun waktu 2003 sampai 2005 tidak ditemukan kasus pengambilan buah konyal secara ilegal di SKW II TNGP. Hal ini bukan berarti di SKW II tidak terdapat buah konyal dan tidak terjadi pengambilan buah konyal secara ilegal. Menurut Ekawati (2000) konyal (Passiflora suberosa) atau dikenal sebagai markisa merupakan salah satu tumbuhan eksotik di TNGP yang mampu berkembang pesat dan menginvasi daerah yang cukup luas bahkan menekan pertumbuhan jenis-jenis asli di sekitarnya. Jenis ini dapat dijumpai di Cisarua sampai pada ketinggian 1.600 m dpl. Buah konyal dapat dimakan dan laku di pasaran sehingga sangat menarik minat masyarakat untuk memungut dan menjualnya. Tanaman konyal hidup sebagai liana dan memanjat pohon asli, tidak jarang masyarakat mengambil buah konyal dengan cara menebang pohon inangnya. Hal ini tentu menimbulkan pengaruh negatif terhadap kelestarian hutan. Berdasarkan data laporan TNGP tahun 2005 pengambilan buah konyal secara ilegal terjadi di SKW I.

\section{Kajian Sosio-Ekonomi Masyarakat Sekitar Kawasan yang Melatarbela- kangi Pengambilan Tumbuhan $\mathrm{Hu}-$ tan secara Ilegal (Bambu dan Kayu Bakar)}

Pengelolaan taman nasional tidak terlepas dari keberadaan masyarakat di sekitar kawasan, dan hal ini sedikit banyak memberikan dampak negatif terhadap kawasan TNGP. Berdasarkan hasil kuesioner dan wawancara terhadap masyarakat di setiap resort didapatkan data bahwa pengambilan tumbuhan hutan secara ilegal yang umum terjadi di setiap resort hanyalah bambu dan kayu bakar, serta tidak didapatkan informasi dari masyarakat untuk jenis-jenis pengambilan secara ilegal lainnya seperti pakis haji, buah konyal, rotan, tanaman hias, kayu pertukangan/ gelondongan, dan lain-lain. Hal ini disebabkan intensitas pengambilan tumbuhan hutan secara ilegal selain bambu dan kayu bakar tersebut tidak sering, bersifat temporer, dan lebih banyak dilakukan oleh oknum di luar kawasan daerah penyangga. Oleh karena itu pembahasan tentang pengambilan tumbuhan hutan secara ilegal di bawah ini dikhususkan untuk pengambilan bambu dan kayu bakar secara ilegal.

1) Jumlah Penduduk yang Menggunakan Bambu dan Kayu Bakar dari Hutan

Informasi mengenai seberapa banyak masyarakat yang menggunakan bambu dan kayu bakar dari hutan dapat menjadi parameter tingkat kerawanan di kawasan tersebut. Hasil wawancara tentang jumlah penduduk yang menggunakan bambu dan kayu bakar dari hutan dapat dilihat di Tabel 3.

Dari Tabel 3 dapat diketahui bahwa tingkat kerawanan masing-masing resort berbeda terhadap pengambilan secara ilegal. Urutan tingkat kerawanan dari yang paling rawan berdasarkan informasi dari masyarakat adalah Resort Cisarua, Resort Cimande, Resort Bodogol, dan Resort 
Tabel (Table) 3. Jumlah penduduk yang menggunakan bambu dan kayu bakar dari hutan berdasarkan informasi responden sekitar kawasan TNGP (Number of local people using bamboo and fuel wood from forest based on respondent information)

\begin{tabular}{lccccc}
\hline \multirow{2}{*}{$\begin{array}{c}\text { Jawaban responden } \\
\text { (Respondent answer) }\end{array}$} & Bodogol & Cisarua & Cimande & Bojong Murni & $\begin{array}{c}\text { Rata-rata } \\
\text { (Average) }\end{array}$ \\
\cline { 2 - 6 } & 100 & 33,3 & 65,4 & 100 & 74,68 \\
Kurang dari 20 orang & 0 & 36,7 & 7,7 & 0 & 11,09 \\
20-50 orang & 0 & 30,0 & 0 & 0 & 7,50 \\
50-100 orang & 0 & 0 & 26,9 & 0 & 6,37 \\
Tidak tahu & & & & & \\
\hline
\end{tabular}

Bojong Murni. Resort Cisarua relatif paling banyak dibanding resort lain disebabkan oleh keberadaan pos pengamanan yang jauh dari penduduk sehingga penduduk leluasa memasuki kawasan hutan. Kantor Resort Cisarua terletak di tepi jalan menuju perkampungan sedangkan pemukiman penduduk lebih dekat dengan hutan sehingga penduduk yang masuk ke hutan luput dari pengawasan. Bagian tumbuhan hutan yang diambil untuk kayu bakar adalah ranting-ranting atau cabang pohon. Penduduk biasanya membawanya dengan berjalan kaki dengan kemampuan rata-rata membawa kayu bakar setiap jiwa/individu berkisar 1-4 pikul. Mereka akan kembali lagi ke hutan setelah kayu bakar tersebut habis. Berdasarkan informasi dari beberapa responden, satu pikul kayu bakar tersebut akan habis dalam jangka waktu sekitar 3-7 hari. Jadi dapat diperkirakan rata-rata 1-4 minggu sekali mereka masuk ke hutan. Sedangkan penduduk yang menggunakan bambu rata-rata mereka masuk ke hutan jika memerlukan untuk pembuatan kandang ternak, rumah atau ajir tanaman; jadi intensitasnya bersifat temporer.

\section{2) Tingkat Pengetahuan dan Pemahaman} Masyarakat tentang Keberadaan TNGP

Tingkat pengetahuan dan pemahaman masyarakat tentang keberadaan TNGP sebagai kawasan konservasi perlu diketahui untuk memperkirakan tingkat kesadaran masyarakat dalam berpartisipasi aktif menjaga kawasan TNGP. Hasil wawancara mengenai tingkat pengetahuan dan pe- mahaman masyarakat tentang keberadaan TNGP dapat dilihat di Tabel 4.

Pada Tabel 4 dapat diketahui bahwa secara umum tingkat pengetahuan dan pemahaman masyarakat tentang kesadaran konservasi dan pelestarian alam di SKW II TNGP masih rendah. Hal ini disebabkan kurangnya sosialisasi dari pihak TNGP kepada masyarakat tentang kesadaran konservasi dan pelestarian alam. Tingkat pemahaman yang rendah berpengaruh terhadap sikap mereka dalam menjaga kawasan konservasi dan pelestarian alam. Menurut Suminar (2001) rendahnya tingkat kesadaran konservasi dan pelestarian alam lebih diakibatkan oleh perbedaan orientasi nilai yang dimiliki oleh individu. Namun demikian persoalan konservasi dan pelestarian lingkungan harus dianalisis dengan mempertimbangkan aspek kesejarahan ditetapkannya kawasan TNGP.

Tingkat pengetahuan dan pemahaman masyarakat dari masing-masing resort tentang TNGP berurutan dari yang terbesar adalah Resort Bodogol, Resort Cisarua, Resort Cimande, dan Resort Bojong Murni. Tingkat pengetahuan dan pemahaman masyarakat di Resort Bodogol tertinggi dibanding dengan yang di resort-resort lain. Hal ini disebabkan karena Resort Bodogol merupakan lokasi Pusat Pendidikan Konservasi Alam yang kegiatannya memberikan penerangan pada masyarakat tentang pentingnya kawasan konservasi sehingga dapat meningkatkan kesadaran masyarakat untuk berperanserta aktif menjaga dan melindungi kawasan TNGP. Dampak positif yang dirasakan 
Tabel (Table) 4. Data tingkat pengetahuan dan pemahaman/persepsi masyarakat tentang keberadaan TNGP (Data of communities knowledge and perception about Gede Pangrango National Park)

\begin{tabular}{lccccc}
\hline \multirow{2}{*}{$\begin{array}{c}\text { Jawaban responden } \\
\text { (Respondent answer) }\end{array}$} & Bodogol & Cisarua & Cimande & Bojong Murni & $\begin{array}{c}\text { Rata-rata } \\
\text { (Average) }\end{array}$ \\
\cline { 2 - 6 } & 64,44 & 40,00 & 38,46 & 17,65 & 40,14 \\
Ya, tahu & 17,24 & 83,33 & 10,00 & 0,00 & 27,64 \\
Tempat wisata & 82,76 & 16,67 & 90,00 & 100,00 & 72,36 \\
Perlindungan dan & 35,56 & 60,00 & 61,54 & 82,35 & 59,86 \\
pelestarian alam & & & & & \multicolumn{3}{c}{ Persentase responden (Respondent percentage) (\%) } \\
Tidak tahu & & &
\end{tabular}

dapat dilihat pada tingkat kerawanan (pengambilan bambu dan kayu bakar secara ilegal) yang relatif rendah sebagaimana ditampilkan dalam Tabel 3.

Responden dari Resort Cisarua yang menjawab tahu tentang keberadaan TNGP sebesar $40 \%$ responden, tetapi dari yang mengaku tahu itu hanya 16,67\% yang menjawab sebagai kawasan perlindungan dan pelestarian alam sedangkan 83,33\% menjawab TNGP sebagai kawasan tempat wisata. Hal ini disebabkan karena di Resort Cisarua terdapat lahan bumi perkemahan dan air terjun yang sering didatangi pengunjung. Pemahaman mereka tentang TNGP sebagai kawasan pelestarian alam yang harus dijaga dan dilindungi masih kurang dan hal ini berdampak negatif pada tingginya jumlah penduduk yang melakukan pengambilan bambu dan kayu bakar secara ilegal.

Responden dari Resort Cimande yang menjawab tahu tentang keberadaan TNGP hanya $38 \%$, dan dari yang mengaku tahu itu $90 \%$ menjawab sebagai kawasan perlindungan dan pelestarian alam sedangkan $10 \%$ sisanya menjawab sebagai tempat wisata. Tingkat pengetahuan yang masih rendah tentang keberadaan TNGP di Resort Cimande disebabkan karena belum banyaknya penerangan kepada masyarakat tentang kawasan konservasi TNGP seperti yang dilakukan di Resort Bodogol. Responden dari Resort Bojong Murni yang menjawab tahu tentang keberadaan TNGP hanya $17,65 \%$, dan semuanya menjawab sebagai kawasan perlindungan dan pelestarian alam. Tingkat pengetahuan yang masih rendah tentang keberadaan TNGP di Resort Bojong Murni mungkin disebabkan resort ini adalah pemekaran dan baru aktif pada tahun 2004 sehingga belum banyak sosialisasi tentang keberadaan kawasan konservasi TNGP.

3) Latar Belakang Penduduk Melakukan Aktivitas Pengambilan Tumbuhan Hutan (Bambu dan Kayu Bakar) Secara Ilegal di Kawasan TNGP

Wawancara dilakukan untuk mengetahui latar belakang yang menyebabkan penduduk melakukan aktivitas pengambilan tumbuhan hutan secara ilegal khususnya bambu dan kayu bakar. Hasil wawancara tersebut dapat dilihat di Tabel 5.

Berdasarkan Tabel 5 dapat diketahui bahwa penyebab yang melatarbelakangi penduduk melakukan aktivitas pengambilan tumbuhan hutan secara ilegal (bambu dan kayu bakar) di setiap resort berbeda. Secara umum sebagian besar responden (88,2\%) melakukan pengambilan bambu dan kayu bakar secara ilegal untuk memenuhi kebutuhan sehari-hari. Berdasarkan wawancara dengan masyarakat, diketahui bahwa mereka melakukan aktivitas pengambilan bambu secara ilegal untuk memenuhi bahan baku pembuatan rumah, kandang ternak, pembuatan kerajinan dan ajir tanaman pertanian. Kepadatan penduduk yang cukup tinggi, rendahnya kesempatan kerja, keterbatasan modal, dan kelemahan penanganan pasca panen menyebabkan penghasilan petani kurang memadai, sehingga dapat dikatakan masyarakat sekitar kawasan TNGP hidup dalam taraf perekonomian rendah. Hal ini yang mendorong penduduk melakukan pengambilan tumbuhan hutan secara ilegal, khususnya bambu dan kayu bakar 
Tabel (Table) 5. Penyebab yang melatarbelakangi penduduk melakukan aktivitas pengambilan tumbuhan hutan secara ilegal (bambu dan kayu bakar) di kawasan TNGP (Reason for illegal taking out forest plants)

\begin{tabular}{lccccc}
\hline \multirow{2}{*}{$\begin{array}{c}\text { Jawaban responden } \\
\text { Respondent answer) }\end{array}$} & Bodogol & Cisarua & Cimande & Bojong Murni & $\begin{array}{c}\text { Rata-rata } \\
\text { (Average) }\end{array}$ \\
\cline { 2 - 6 } & 88,9 & 96,7 & 73,1 & 94,1 & 88,2 \\
A & 0 & 3,3 & 0 & 5,9 & 2,3 \\
B & 11,1 & 0 & 0 & 0 & 2,8 \\
C & 0 & 0 & 26,9 & 0 & 6,7 \\
Tidak Tahu & & \multicolumn{4}{c}{ Persentase responden (Respondent percentage) (\%) } \\
\hline
\end{tabular}

Keterangan :A. Karena untuk memenuhi kebutuhan sehari-hari (To fulfill daily need); B. Karena perintah orang lain (tetangga) yang akan membeli hasilnya (Based on other person's command who will pay its yield); C. Karena sudah menjadi kebiasaan dan penduduk menganggap dibolehkan mengambil secara bebas/gratis (Considered as usual and allowable activities).

untuk memenuhi kebutuhan hidup seharihari. Menurut Suminar (2001) upaya untuk mempertahankan kelangsungan ekonomi keluarga telah ditempatkan lebih tinggi dibandingkan hanya sekedar melakukan upaya konservasi dan pelestarian hutan.

Besarnya persentase responden yang menyatakan latar belakang pengambilan tumbuhan hutan secara ilegal untuk memenuhi kebutuhan sehari-hari menunjukkan bahwa sebagian besar pelaku pengambilan bambu dan kayu bakar secara ilegal adalah masyarakat sekitar. Hal ini dibuktikan juga dengan kecilnya persentase responden yang menyatakan pengambilan secara ilegal dilakukan karena perintah orang lain yang akan membeli hasilnya. Kondisi ini menunjukkan bahwa pendekatan dan pembinaan pada masyarakat sekitar sangat diperlukan untuk mengatasi gangguan keamanan kawasan hutan. Terlebih dengan adanya anggapan masyarakat yang mengambil tumbuhan hutan secara illegal sudah merupakan kebiasaan sejak dulu, dapat membahayakan kelestarian hutan bila tidak dikendalikan sedini mungkin sebab anggapan ini dapat menjadi budaya dan turun-temurun yang sulit dikendalikan.

4) Pekerjaan Penduduk yang Melakukan Aktivitas Pengambilan Tumbuhan Hutan Secara Ilegal

Informasi mengenai pekerjaan para pelaku pengambilan tumbuhan hutan secara ilegal (bambu dan kayu bakar) dapat menggambarkan kapasitas keterampilan dan pendapatannya sehingga dapat dijadikan pertimbangan dalam mencari jalan pemecahan yang tepat. Hasil wawancara dengan masyarakat di setiap resort dapat dilihat pada Tabel 6 .

Berdasarkan Tabel 6 dapat diketahui bahwa sebagian besar responden yang melakukan aktivitas pengambilan tumbuhan hutan secara ilegal khususnya bambu dan kayu bakar berprofesi sebagai buruh. Banyaknya penduduk berprofesi buruh yang melakukan pengambilan tumbuhan hutan secara illegal mungkin disebabkan pendapatan mereka yang kecil. Buruh juga tidak mempunyai lahan garapan yang menetap sehingga mereka sangat tergantung pada permintaan orang lain yang akan mempekerjakan. Buruh akan mudah dipekerjakan oleh siapa saja yang bersedia membayarnya dan hal ini sangat berpotensi untuk dimanfaatkan para cukong kayu yang mempunyai modal besar untuk mempekerjakan mereka melakukan aktivitas pengambilan tumbuhan hutan secara ilegal. Walaupun dalam kasus ini belum ditemukan kasus cukong-cukong besar yang mempekerjakan mereka, tetapi didapatkannya informasi bahwa pengambilan tanaman pakis secara illegal disebabkan ada pihak ketiga yang bersedia menampung hasilnya. Dalam tingkat kecil pun ada beberapa orang yang membayar para buruh untuk mengambil tumbuhan hutan secara ilegal berupa bambu dan kayu bakar untuk kepentingan pribadi. 
Tabel (Table) 6. Pekerjaan penduduk yang melakukan pengambilan tumbuhan hutan secara ilegal berdasarkan resort (Occupation of people illegally taking out forest plants by resort)

\begin{tabular}{lccccc}
\hline \multirow{2}{*}{$\begin{array}{c}\text { Jawaban responden } \\
\text { (Respondent answer) }\end{array}$} & Bodogol & Cisarua & Cimande & Bojong Murni & $\begin{array}{c}\text { Rata-rata } \\
\text { (Average) }\end{array}$ \\
\cline { 2 - 6 } & 62,2 & 56,7 & 57,7 & 88,2 & 66,2 \\
Buruh & 35,6 & 40,0 & 15,4 & 5,9 & 24,2 \\
Petani & 2,2 & 0,0 & 0,0 & 0,0 & 0,6 \\
Peternak domba & 0,0 & 0,0 & 0,0 & 5,9 & 1,5 \\
Buruh dan petani & 0,0 & 3,3 & 0,0 & 0,0 & 0,8 \\
Pengangguran & 0,0 & 0,0 & 26,9 & 0,0 & 7,0 \\
Tidak tahu & & & & & \\
\hline
\end{tabular}

Tetapi berdasarkan informasi responden kebanyakan dari buruh melakukan aktivitas pengambilan tumbuhan hutan secara ilegal terutama bambu dan kayu bakar hanyalah untuk memenuhi kebutuhan sehari-hari. Misalnya kebutuhan akan bahan bakar yang digantikan dengan kayu bakar, menjual kayu bakar/bambu ke tetangga untuk menambah pendapatan mereka dalam memenuhi kebutuhan seharihari, dan menggunakan bambu untuk membuat kandang ternak atau rumah.

Petani juga melakukan aktivitas pengambilan tumbuhan hutan secara ilegal di dalam kawasan. Hal ini mereka lakukan karena petani membutuhkan ajir-ajir untuk tanaman pertanian. Petani juga menggunakan bahan bakar berupa kayu bakar untuk memenuhi kebutuhan sehari-hari mereka. Peternak domba mengambil bambu secara ilegal biasanya untuk bahan baku pembuatan kandang ternak. Para pengangguran dalam jumlah yang kecil juga melakukan aktivitas pengambilan tumbuhan hutan secara ilegal. Hal ini mungkin disebabkan untuk mengisi waktu mereka, mendapatkan penghasilan, memenuhi kebutuhan sehari-hari, dan perintah orang lain. Berdasarkan informasi responden penghasilan petani, buruh, dan peternak domba rata-rata masih di bawah Upah Minimum Regional (UMR) sehingga tidak cukup untuk memenuhi kebutuhan sehari-hari. Secara garis besar kondisi perekonomian yang mendesak mengakibatkan mereka melakukan aktivitas pengambilan tumbuhan hutan secara ilegal di dalam kawasan TNGP. Dengan demikian tingkat ketergantungan terhadap kawasan akan berpotensi terhadap kerusakan hutan sehingga perlu penanganan khusus dalam mengantisipasinya. Hal ini disebabkan kondisi sosial ekonomi dan karakteristik masyarakat sangat mempengaruhi perilaku mereka dalam berinteraksi dengan hutan. Menurut Suminar (2001) hambatan sosial ekonomi yang saat ini dihadapi masyarakat menjadi salah satu faktor yang mendorong munculnya tekanan terhadap taman nasional.

5) Penghasilan Penduduk yang Melakukan Aktivitas Pengambilan Tumbuhan Hutan Secara Ilegal (Bambu dan Kayu Bakar)

Informasi mengenai penghasilan pela$\mathrm{ku}$ pengambilan tumbuhan hutan secara ilegal dapat menggambarkan seberapa besar tingkat kesejahteraan/kondisi sosial ekonomi masyarakat, sehingga dapat diketahui salah satu faktor penyebab pengambilan tumbuhan hutan secara ilegal di dalam kawasan TNGP. Hasil wawancara dengan masyarakat sekitar kawasan tentang tingkat penghasilan penduduk yang melakukan aktivitas pengambilan tumbuhan hutan secara ilegal khususnya bambu dan kayu bakar dapat dilihat di Tabel 7.

Berdasarkan Tabel 7 disebutkan bahwa responden di sekitar SKW II memiliki tingkat kesejahteraan yang relatif rendah yaitu kurang dari Rp 100.000,- per bulan. Tingkat kesejahteraan penduduk yang sangat rendah mendorong mereka masuk ke kawasan konservasi untuk melakukan 
Tabel (Table) 7. Penghasilan penduduk yang melakukan aktivitas pengambilan tumbuhan hutan secara ilegal berdasarkan resort (Income of people illegaly taking out forest plants by resort)

\begin{tabular}{lccccc}
\hline \multirow{2}{*}{$\begin{array}{c}\text { Jawaban responden } \\
\text { (Respondent answer) }\end{array}$} & Bodogol & Cisarua & Cimande & Bojong Murni & $\begin{array}{c}\text { Rata-rata } \\
\text { (Average) }\end{array}$ \\
\cline { 2 - 6 } & 26,7 & 40,0 & 73,1 & 100,0 & 59,9 \\
\hline Kurang dari Rp 100.000,- & 33,3 & 40,0 & 0,0 & 0,0 & 18,3 \\
Rp 100.000,00 - Rp 250.000,- & 40,0 & 20,0 & 0,0 & 0,0 & 15,0 \\
Rp 250.000,00 - Rp 500.000,- & 0,0 & 0,0 & 26,9 & 0,0 & 6,7 \\
Tidak tahu & & & & & \\
\hline
\end{tabular}

Tabel (Table) 8. Tingkat pendidikan penduduk yang melakukan aktivitas pengambilan tumbuhan hutan secara ilegal berdasarkan resort (Education of people illegaly taking out forest plants by resort)

\begin{tabular}{lccccc}
\hline \multirow{2}{*}{$\begin{array}{c}\text { Tingkat pendidikan } \\
\text { (Education level) }\end{array}$} & Bodogol & Cisarua & Cimande & Bojong Murni & $\begin{array}{c}\text { Rata-rata } \\
\text { (Average) }\end{array}$ \\
\cline { 2 - 6 } & 95,6 & 100,0 & 73,1 & 100,0 & 92,2 \\
SD & 4,4 & 0,0 & 26,9 & 0,0 & 7,8 \\
SMP & 0,0 & 0,0 & 0,0 & 0,0 & 0,0 \\
SMA & 0,0 & 0,0 & 26,9 & 0,0 & 6,7 \\
Tidak tahu & & & & & \\
\hline
\end{tabular}

pengambilan tumbuhan hutan secara ilegal dalam rangka memenuhi kebutuhan hidup sehari-hari. Sebagaimana pendapat Wibowo (1990) dalam Silfiyani (2004) bahwa kondisi sosial ekonomi masyarakat yang rendah merupakan salah satu faktor terjadinya gangguan terhadap kawasan oleh masyarakat. Taman nasional menjadi sumber mata pencaharian pokok bagi masyarakat yang tidak memiliki lahan pertanian. Memasuki kawasan merupakan pekerjaan selingan apabila tidak menggarap lahan.

6) Tingkat Pendidikan Penduduk yang Melakukan Aktivitas Pengambilan Tumbuhan Hutan Secara Ilegal

Tingkat pendidikan responden yang melakukan aktivitas pengambilan tumbuhan hutan secara ilegal di dalam kawasan TNGP (Tabel 8) dapat menunjukkan seberapa besar tingkat pengetahuan, pemahaman, dan kemampuan mereka. Dengan diketahuinya hal ini maka dapat dicari kemungkinan jalan pemecahan yang sesuai dengan kapasitas mereka.

Berdasarkan Tabel 8 dapat diketahui bahwa sebagian besar (92,2\%) tingkat pendidikan responden yang melakukan aktivitas pengambilan tumbuhan hutan se- cara ilegal (bambu dan kayu bakar) adalah Sekolah Dasar. Bahkan di Resort Cisarua dan Bojong Murni 100\% responden menyatakan bahwa pelaku pengambilan tumbuhan hutan secara ilegal berpendidikan terakhir hanya SD. Tingkat pendidikan yang rendah juga diduga mempengaruhi tingkat pengetahuan dan pemahaman tentang TNGP sebagai kawasan yang harus dijaga dan dilindungi. Tingkat pendidikan yang rendah juga mengakibatkan kemampuan terbatas dalam mencari pekerjaan sehingga mereka melakukan aktivitas pengambilan tumbuhan hutan secara ilegal (bambu dan kayu bakar) untuk memenuhi kebutuhannya. Hal ini sesuai dengan hasil penelitian Rosanto dan Priatna (1982) dalam Kusnanto (2000), interaksi masyarakat dengan hutan taman nasional yang berdampak negatif dapat disebabkan antara lain karena meningkatnya laju pertumbuhan penduduk, pemilikan lahan makin sempit, serta pendidikan dan persepsi yang rendah. Masyarakat di dalam dan di sekitar hutan banyak menggantungkan hidupnya pada keberadaan hutan dan memiliki hubungan erat dengan hutan (Departemen Kehutanan dan Perkebunan, 2000 dalam Subaktini, 2006). 


\section{KESIMPULAN DAN SARAN}

\section{A. Kesimpulan}

1. Jenis-jenis pengambilan tumbuhan hutan secara ilegal yang terjadi di Seksi Konservasi Wilayah (SKW) II Taman Nasional Gunung Gede Pangrango (TNGP) adalah kayu pertukangan, kayu bakar, bambu, pakis, dan tanaman hias, dengan pelaku berasal dari masyarakat sekitar hutan dan oknum masyarakat di luar kawasan. Intensitas kasus pengambilan tumbuhan hutan secara ilegal tahun 2005 untuk setiap resort di SKW II TNGP adalah Resort Cisarua sembilan kasus, Resort Bojong Murni 11 kasus, Resort Cimande tiga kasus, dan Resort Bodogol 14 kasus.

2. Pengambilan tumbuhan hutan secara ilegal jenis kayu bakar merupakan gangguan yang dominan di SKW II TNGP karena terjadi di semua resort dan terjadi hampir sepanjang tahun 2005. Pengambilan kayu bakar secara ilegal semakin meningkat dalam kurun waktu 2003-2005; pada tahun 2003 tercatat 16 pikul, kemudian pada tahun 2004 tercatat 32 pikul, dan pada tahun 2005 mencapai 93 pikul.

3. Berdasarkan jumlah responden yang mengambil tumbuhan hutan secara ilegal, urutan tingkat kerawanan terhadap gangguan hutan dari yang paling rawan adalah Resort Cisarua. Menyusul kemudian adalah Resort Cimande, Resort Bodogol, dan Resort Bojong Murni.

4. Tingkat pengetahuan dan pemahaman masyarakat tentang keberadaan TNGP sebagai kawasan konservasi yang dijaga dan dilindungi kelestariannya relatif masih rendah. Hal ini dapat dilihat dari 59,9\% responden yang belum tahu keberadaan taman nasional. Pengetahuan dan pemahaman masyarakat dari masing-masing resort tentang TNGP dari yang tertinggi adalah Resort Bodogol, Resort Cisarua, Resort Cimande, dan Resort Bojong Murni.
5. Sebagian besar responden sekitar hutan melakukan pengambilan tumbuhan hutan secara ilegal (bambu dan kayu bakar) untuk memenuhi kebutuhan sehari-hari (88,2\%), sebagian kecil karena perintah orang lain yang akan membeli hasilnya (2,3\%), atau karena sudah menjadi kebiasaan dan menganggap sebagai tindakan yang diperbolehkan $(2,8 \%)$

6. Tingkat pendidikan dan pendapatan yang rendah mendorong masyarakat sekitar hutan melakukan gangguan pada hutan. Responden yang melakukan pengambilan tumbuhan hutan secara ilegal (bambu dan kayu bakar) sebagian besar adalah buruh (66,2\%) yang ra-ta-rata berpendidikan Sekolah Dasar (92,2\%) dan berpenghasilan di bawah Rp 100.000,- per bulan (59,9\%).

\section{B. Saran}

1. Perlu adanya penelitian teknologi (model agroforestry) yang sesuai dikembangkan di sekitar kawasan TNGP untuk usaha peningkatan kesejahteraan masyarakat.

2. Evaluasi bentuk-bentuk usaha pedesaan yang telah dikembangkan sehingga dapat mengetahui efektivitasnya dalam usaha peningkatan kesejahteraan masyarakat dan partisipasi masyarakat da-lam pengamanan hutan.

3. Evaluasi sistem pengamanan terhadap kawasan yang memberi informasi seberapa efektif telah menekan tingkat gangguan terhadap kawasan.

\section{DAFTAR PUSTAKA}

Ekawati, D. M. 2000. Pola Umum Gangguan Hutan di Taman Nasional Gunung Gede Pangrango. Skripsi Jurusan Konservasi Sumber Daya Hutan. IPB. Bogor.

Kemenetrian Lingkungan Hidup. 2003. Rencana dan Progam Kementerian Lingkungan Hidup. Jakarta. 
Kusnanto, K. 2000. Bentuk-Bentuk dan Intensitas Gangguan Manusia Pada Daerah Tepi Kawasan Taman Nasional Gunung Gede Pangrango. Skripsi Jurusan Konservasi Sumber Daya Hutan. IPB. Bogor.

PPKAB. 1999. Laporan Kegiatan Pusat Pendidikan Konservasi Alam Bodogol. Seksi Konservasi Wilayah II. Taman Nasional Gunung Gede Pangrango. Cibodas.

Silfiyani, D. 2004. Tingkat Partisipasi Masyarakat Dalam Menjaga Kelestarian Kawasan Taman Nasional Gunung Gede Pangrango. Tugas Akhir Jurusan Manajemen Hutan IPB. Bogor.

Subaktini, D. 2006. Analisis Sosial Ekonomi Masyarakat di Zona Rehabilitasi Taman Nasional Meru Betiri Jember. Jawa Timur.
Suminar, P. 2001. Orientasi Nilai dan Kesadaran Konservasi Hutan Pada Masyarakat Sekitar Kawasan Taman Nasional Kerinci Seblat. Jurnal Penelitian UNIB VII (2).

TN Gunung Gede Pangrango (TNGP). 2003. Laporan Tahunan Seksi Konservasi Wilayah II Taman Nasional Gunung Gede Pangrango. TN Gunung Gede Pangrango. Cibodas. 2004.

Laporan Tahunan Seksi Konservasi Wilayah II Taman Nasional Gunung Gede Pangrango. TN Gunung Gede Pangrango. Cibodas.

2005.

Laporan Bulanan Seksi Konservasi Wilayah II Taman Nasional Gunung Gede Pangrango Bulan Januari-Desember. TN Gunung Gede Pangrango. Cibodas. 